\title{
Diversity and aboveground biomass of lianas in the tropical seasonal rain forests of Xishuangbanna, SW China
}

\author{
Xiao-Tao Lü ${ }^{1}$, Jian-Wei Tang ${ }^{1 *}$, Zhi-Li Feng ${ }^{1} \&$ Mai-He Li ${ }^{2,3 *}$
}

1. Xishuangbanna Tropical Botanical Garden, Chinese Academy of Sciences, Menglun Town, Mengla County, Yunnan 666303, China.

2. Swiss Federal Institute for Forest, Snow and Landscape Research WSL, Zuercherstrasse 111, CH-8903 Birmensdorf, Switzerland.

3. Institute of Mountain Hazards and Environment, Chinese Academy of Sciences, Chengdu 610041, China

* Co-corresponding authors; Tel: +86 691 8715080; fax: +86691 8715070; tangjw@xtbg.org.cn; maihe.li@wsl.ch

\author{
Received 04-III-2008. Corrected 10-VII-2008. Accepted 12-VIII-2008.
}

\begin{abstract}
Lianas are important components of tropical forests and have significant impacts on the diversity, structure and dynamics of tropical forests. The present study documented the liana flora in a Chinese tropical region. Species richness, abundance, size-class distribution and spatial patterns of lianas were investigated in three 1-ha plots in tropical seasonal rain forests in Xishuangbanna, SW China. All lianas with $\geq 2 \mathrm{~cm}$ diameter at breast height ( $\mathrm{dbh}$ ) were measured, tagged and identified. A total of 458 liana stems belonging to 95 species (ranging from 38 to 50 species/ha), 59 genera and 32 families were recorded in the three plots. The most well-represented families were Loganiaceae, Annonceae, Papilionaceae, Apocynaceae and Rhamnaceae. Papilionaceae (14 species recorded) was the most important family in the study forests. The population density, basal area and importance value index (IVI) varied greatly across the three plots. Strychnos cathayensis, Byttneria grandifolia and Bousigonia mekongensis were the dominant species in terms of IVI across the three plots. The mean aboveground biomass of lianas (3 $396 \mathrm{~kg} / \mathrm{ha}$ ) accounted for $1.4 \%$ of the total community aboveground biomass. The abundance, diversity and biomass of lianas in Xishuangbanna tropical seasonal rain forests are lower than those in tropical moist and wet forests, but higher than those in tropical dry forests. This study provides new data on lianas from a geographical region that has been little-studied. Our findings emphasize that other factors beyond the amount and seasonality of precipitation should be included when considering the liana abundance patterns across scales. Rev. Biol. Trop. 57 (1-2): 211-222. Epub 2009 June 30.
\end{abstract}

Key words: biodiversity, liana abundance, liana biomass, species richness, tropical forests.

The woody climbing plants, lianas, are important components of tropical forests. They typically rely on other plants for mechanical support and are abundant, diverse, and make a significant contribution (10-25\%) to the overall plant diversity in the tropical forests (Gentry and Dodson 1987, Nabe-Nielsen 2001). Before the 1980 s, limited attention is paid to lianas in the tropical forest. Recent years, however, more and more studies about lianas have been conducted due to the awareness of the important role of lianas in the tropical forest ecosystems (Schnitzer 2005, Gerwing et al. 2006). Even though, the ecology of lianas in most forests is still poorly understood (Mascaro et al. 2004).

Lianas have been found to play a vital role in many aspects of forest ecosystem dynamics and functioning, including reducing treegrowth rates (Putz 1984), suppressing tree regeneration (Schnitzer et al. 2000), providing valuable food sources for insects and animals (Nabe-Nielsen 2001), physically linking trees together and thereby increasing community stability and providing canopy-to-canopy access for arboreal animals (Schnitzer and Bongers 2002). However, we still have only a vague 
idea of the liana composition of most tropical forests and know little about the role that lianas play in these forests (Burnham 2004).

The richness and abundance of lianas varied greatly with forest ecosystems and/or forest locations, depending on varying biotic and abiotic factors (DeWalt et al. 2000, Reddy and Parthsarathy 2003, Rice et al. 2004, Schnitzer 2005). Gentry (1991) suggested that lianas abundance is mainly determined by the seasonality of precipitation, and lianas were more abundant in tropical moist forests than in tropical wet and dry forests. Based on data gained from 69 tropical forests worldwide, Schnitzer (2005) demonstrated that liana abundance is negatively correlated with mean annual precipitation and positively with seasonality. Moreover, Putz (1983) and Schnitzer and Bongers (2002) suggested that lianas are strongly dependent on the availability of treefall gaps in dense tropical forests. Hence, the occurrence of lianas is positively correlated with the intensity of forest disturbances and negatively with stand biomass (Laurence et al. 2001, Reddy and Parthsarathy 2003).

The Xishuangbanna region is famous in China for its diverse flora and fauna. Comparing with other tropical forest regions, the annual rainfall in this region is relatively low $(1500 \mathrm{~mm})$ with a five-month long dry season. Due to its unique geographical and climatic features, this area supports a tropical rain forest with a small proportion of deciduous tree species that shed leaves in different seasons (Cao et al. 1996). The tropical seasonal rain forest is the dominant forest type in this area (Cao and Zhang 1997). Several studies dealing with the floristic and ecological features of the tree layers in the seasonal rain forests in Xishuangbanna have been carried out (Cao and Zhang 1997, Feng et al. 1998, Shanmughavel et al. 2001, Zhu et al. 2004). To our knowledge, however, the diversity and biomass of lianas have neither yet been studied in the Xishuangbanna tropical forests nor even in any of China's tropical regions. To fill this knowledge gap, the present paper reports the abundance, diversity and aboveground biomass of lianas, based on data gained from permanent plots established in several primary tropical rain forests in Xishuangbanna.

\section{MATERIALS AND METHODS}

The study was carried out in Xishuangbanna $\left(21^{\circ} 09^{\prime}-22^{\circ} 36^{\prime} \mathrm{N}\right.$ and $\left.99^{\circ} 58^{\prime}-101^{\circ} 50^{\prime} \mathrm{E}\right)$, which borders Laos and Myanmar on the upper course of the Mekong River. Three plots (1 hectare each, $100 \times 100 \mathrm{~m}$ ) were established in the tropical seasonal rain forests located in wet valleys. The region experiences a typical tropical monsoon climate with a rainy season between May and October and a dry season between November and April. Xishuangbanna is an inland region with low wind speeds. Therefore, the forests have been protected from catastrophic disturbance by hurricanes. The climate data $(1959$ - 2002) were collected at a weather station $\left(21^{\circ} 55^{\prime} \mathrm{N}, 101^{\circ} 15^{\prime} \mathrm{E}, 600\right.$ $\mathrm{m}$ a.s.l.; Xishuangbanna Tropical Rainforest Ecosystem Station), located approximately 5 $\mathrm{km}$ from the Menglun plot and $60 \mathrm{~km}$ from the other two plots: annual mean air temperature, $21.7^{\circ} \mathrm{C}$; mean temperature for the hottest month (June), $25.7^{\circ} \mathrm{C}$; mean temperature for the coldest month (January), $15.9^{\circ} \mathrm{C}$, and mean annual precipitation, $1539 \mathrm{~mm}$ (of which $87 \%$ occurs in the rainy season and $13 \%$ in the dry season). During the dry season, fog occurs almost every day and is heaviest from midnight until midmorning, which tends to compensate for the shortage of rain. The mean relative humidity is $87 \%$. The soil belongs to latosol ( $\mathrm{pH} 4.5-5.5$ ), developed from purple sandstone.

The forests studied are undisturbed oldgrowth forests $(>40 \mathrm{~m}$ in height) with three layers of canopy. The top tree layer $(>35 \mathrm{~m}$ in height) had a crown coverage of $\sim 15 \%$, dominated by Pometia tomentosa (Bl.) Tewsm. et Binn. (Sapindaceae), Terminalia myriocarpa Van Heurck \& Mull.-Arg. (Combretaceae), and Garuga floribunda Decne. var. gamblai (King et Smith) Kalkm (Burseracae). The second layer (20-35 $\mathrm{m}$ in height with continuous crown coverage) consists of Barringtonia macrostachya (Jack) Kurz, Chisocheton siamensis 
Craib, Beilschmiedia brachythyrsa H. W. Li, Gironniera subaequalis Planch. The saplingshrub layer is $1-5 \mathrm{~m}$ tall with a coverage of $\sim 30 \%$. Under the closed canopies there is only sparse ground vegetation consisting mainly of herbs (e.g. Elatostema parvum (B1.) Miq., Pseudoranthemum malaccense) and ferns (e.g. Tectaria polymorpha (Wall. ex Hook.) Cop., Ctenitopsis fuscipes (Wall.) C. Chr. ex Tard.Blot \& C. Chr., Pronephrium nudatum (Roxb.) Holtt.). The mean stand density of trees with $\geq 10 \mathrm{~cm}$ dbh (diameter at breast height of 1.3 m) was 393-466 stems and the mean basal area reached 30.11-40.02 $\mathrm{m}^{2}$ per hectare (Table 1).

Field work was carried out from January to April 2005. Each plot (1 hectare) was divided into 100 subplots $(10 \times 10 \mathrm{~m})$. All trees and lianas with $\geq 2 \mathrm{~cm}$ dbh found in the subplots were numbered, measured, and labeled with aluminum tags. Liana diameter was measured on each rooted stem at breast height $(1.3 \mathrm{~m})$ above the level of the ultimate rooting point to avoid making multiple measurements on stems that had fallen down from the canopy and rerooted. Liana shoots originating from the same main stem were regarded as one plant. The location of each liana stem investigated was mapped in each subplot. All lianas ( $\mathrm{dbh} \geq 2 \mathrm{~cm}$ ) rooted in the plots were identified. The nomenclature of families, genera and species followed Li et al. (1996).

Species richness was determined by the number of species for each plot. Fisher's $\alpha$ (Fisher et al. 1943), Shannon-Wiener index $H^{\prime}$ (Magurran 1988), Simpson's index $\lambda$ (Magurran 1988), and Hill diversity N1 and N2 (Hill 1973) were calculated.
Species abundance was categorized into four classes: dominant (with $>20$ individuals), common (11-20), rare (3-10) and very rare species (1-2). The importance value index (IVI) represents the relative importance of a species in a given community. The IVI is defined as the sum of relative density, relative dominance and relative frequency (Curtis and Cottam 1962). The family importance value (FIV) was calculated according to Mori et al. (1983).

The species-area curve was plotted with respect to species accumulation by sequential arrangement of $100 \mathrm{~m} \times 10 \mathrm{~m}$ subplots. A limited randomization procedure (Nabe-Nielsen 2001) was used.

We harvested and weighed 25 individuals of lianas (dbh ranging from 1.8 to $14.5 \mathrm{~cm}$ ) of 9 most common species outside plots in the surrounding forests, to find a relationship between the aboveground biomass and the dbh for estimating the biomass. The 25 individuals were collected entirely, in combination with a tree biomass study using tree-felling. Fresh leaves and stems of the lianas harvested were collected separately and weighed in the field. The dry mass of the stems and leaves was calculated using a ratio of dry mass to fresh mass derived from sub-samples that had been weighed after oven-drying to constant weight at $75^{\circ} \mathrm{C}$.

\section{RESULTS}

Species diversity: A total of 458 individuals of lianas ( $\geq 2 \mathrm{~cm} \mathrm{dbh}$ ), belonging to 95 liana species, 59 genera and 32 families were counted in the three plots (Table 2). The mean species

TABLE 1

Characteristics of plots in the tropical seasonal rain forest in Xishuangbanna, SW China

\begin{tabular}{lccccccc}
\multicolumn{1}{c}{ Plots } & $\begin{array}{c}\text { Lat. } \\
(\mathrm{N})\end{array}$ & $\begin{array}{c}\text { Long. } \\
(\mathrm{E})\end{array}$ & $\begin{array}{c}\text { Altitude } \\
(\mathrm{m} \text { a.s.1. })\end{array}$ & Aspect & $\begin{array}{c}\text { Slope } \\
\left({ }^{\circ}\right)\end{array}$ & $\begin{array}{c}\text { Tree density per hectare } \\
(\geq 10 \mathrm{~cm} \mathrm{dbh})\end{array}$ & $\begin{array}{c}\text { Basal area of trees per } \\
\text { hectare }\left(\mathrm{m}^{2}\right)\end{array}$ \\
Menglun & $21^{\circ} 57^{\prime}$ & $101^{\circ} 12^{\prime}$ & 730 & NW & $15-20$ & 393 & 30.11 \\
Mengla & $21^{\circ} 32^{\prime}$ & $101^{\circ} 33^{\prime}$ & 581 & EN & $25-30$ & 426 & 40.02 \\
Manyang & $21^{\circ} 27^{\prime}$ & $101^{\circ} 36^{\prime}$ & 643 & NE & $20-25$ & 466 & 31.28
\end{tabular}


TABLE 2

Liana $(\geq 2 \mathrm{~cm}$ dbh) diversity in the three plots in the tropical seasonal rain forests in Xishuangbanna, SW China

$\begin{array}{lccccc} & \text { Menglun } & \text { Mengla } & \text { Manyang } & \text { Total } & \text { Average } \\ \text { Species richness } & 50 & 38 & 44 & 95 & 44 \\ \text { Number of genera } & 37 & 28 & 31 & 59 & 32 \\ \text { Number of families } & 23 & 19 & 22 & 32 & 21 \\ \text { Density (stems per hectare) } & 207 & 137 & 112 & 456 & 152 \\ \text { Shannon-Weiner index } & 3.34 & 3.01 & 3.35 & & \\ \text { Simpson index } & 0.054 & 0.093 & 0.048 & & \\ \text { Fisher's } \alpha \text { index } & 21.63 & 17.41 & 26.26 & \\ \text { Hill's N1 } & 28.22 & 20.29 & 28.50 & \\ \text { Hill's N2 } & 18.52 & 10.75 & 20.83 & & \\ \text { Evenness } & 0.849 & 0.827 & 0.885 & \end{array}$

richness was 44 species per one 1-ha plot, ranging from 38 (Mengla plot) to 50 species (Menglun plot) (Table 2). Only 8 species $(8.4 \%$ of the total 95 species) were present in all three plots, whereas 65 species (70\%) occurred only in one of the three plots, and 22 species $(23 \%)$ were shared by two of the three plots.

The diversity indices varied among the three plots, and no consistent trend could be found (Table 2). The Manyang plot showed the highest values of the diversity indices, except for the Simpson index, whereas the Mengla plot had the smallest values, except for the Shannon-Wiener index. The Menglun plot, which had the highest species richness, showed only intermediate values for the other diversity indices (Table 2).

Density and basal area of lianas decreased consistently from the Menglun plot (207 individuals and $0.47 \mathrm{~m}^{2}$ per hectare), over the Mengla plot (137 and 0.32) to the Manyang plot (114 and 0.27) (Table 2). However, the mean basal area was $23.9 \mathrm{~cm}^{2}$ per liana stem in the Manyang plot, $23.3 \mathrm{~cm}^{2}$ in the Mengla plot and $20.9 \mathrm{~cm}^{2}$ in the Menglun plot.

Species-area curves: Species numbers tended similarly to increase with increasing area sampled for each of the three study plots (Fig. 1). However, this effect of increasing area on species number stopped once the sampled area reached 0.9 hectare in the Mengla plot, while species numbers still increased with increasing sample area in the other two plots (Fig. 1). This indicates that the plot size of one hectare was insufficient to cover the majority of liana species occurring in the tropical seasonal rain forest of Xishuangbanna. The plot size should be larger than 1 ha for further researches in this area.

Abundance of lianas: The abundance of liana species in the three plots varied greatly, ranging from as high as 38 individuals for Byttneria grandifolia (Sterculiaceae) to as low as only one individual for 28 species, e.g. Uncaria macrophylla (Rubiaceae), Kadsura anamosma (Schizandraceae), Sabia parviflora (Sabiaceae), for the three plots.

Only four species, namely Byttneria grandifolia, Strychnos wallichiana, Strychnos cathayensis and Strychnos nitida, were dominant across the three plots. These four species accounted for $25.0 \%$ of the total liana stems and for $26.8 \%$ of the total basal area of lianas. Ten species $(10.5 \%$ of the total 95 liana species) fell into the 'common' species category, which accounted for $28.9 \%$ of the total liana stems and for $28.8 \%$ of the total liana basal area. Thirty-one species $(32.6 \%$ of the total 


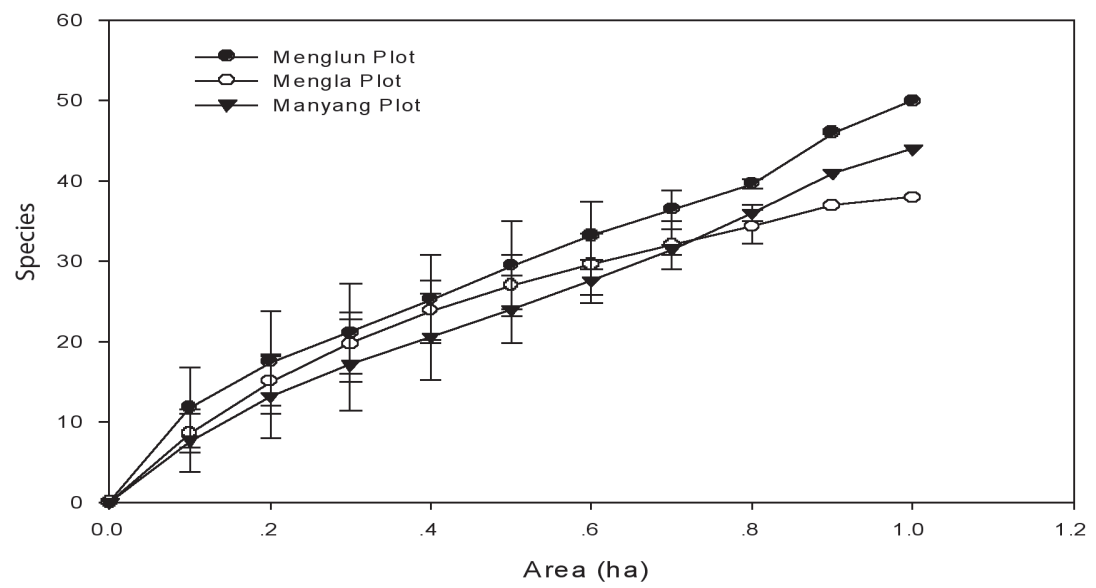

Fig. 1. Species-area curves $( \pm \mathrm{SD})$ for lianas with $\geq 2 \mathrm{~cm}$ dbh in the three plots studied in Xishuangbanna's tropical seasonal rain forests, SW China.

95 liana species) belonged to the 'rare' species category. They made up $31.1 \%$ of the total liana stems and $28.7 \%$ of the total liana basal area. More than half of the liana species enumerated in the three plots ( 49 species) occurred with one or two individuals only, and belonged to "very rare' species. These species accounted for only $14.9 \%$ of the total liana stems and for $15.6 \%$ of the total liana basal area in the three plots.

Plotwise, all the four dominant species ( $B$. grandifolia, $S$. wallichiana, $S$. cathayensis and S. nitida) occurred in the Menglun plot, but S. cathayensis (with a total of 28 individuals) occurred only in this plot. Each of the other two plots had only two out of the four dominant species, namely $B$. grandifolia and $S$. nitida in the Mengla plot, and $S$. wallichiana and $S$. nitida in the Manyang plot (Appendix 1). Only S. nitida was found in all of the three plots.

The majority of the species and the stems belonged to the smaller diameter classes (Table 3). Sixty-nine species out of the 95 species counted in the three plots were in the 2-4 $\mathrm{cm}$ dbh class. Ninety percent of liana stems occurred with $<8 \mathrm{~cm}$ dbh, of which $50 \%$ were concentrated in the $2-4 \mathrm{~cm}$ dbh class. Only 16 stems, belonging to 11 species, had a dbh $>10$ $\mathrm{cm}$ (Table 3), and only one stem with a dbh $>15 \mathrm{~cm}$. This suggests that the size of the most liana species occurred in this area is small. The Mengla plot had seven individuals with $>10 \mathrm{~cm}$ $\mathrm{dbh}$, each of the other two plots had five such individuals (Table 3).

Importance value index (IVI) and family importance value (FIV): The two most important species for the three plots were $B$. grandifolia with an IVI of 79.4, and $S$. nitida with an IVI of 66.9. At the plot level, S. cathayensis was the most important species for the Menglun plot, $B$. grandifolia for the Mengla plot, and B. mekongensis for the Manyang plot (Appendix 1).

The number of genera and species, the densities and the family importance values (FIV) of all liana families varied greatly among plots (Appendix 2). The species number of a family varied from 1 to 14 . Fourteen families ( $45 \%$ of the total number of families found) were represented by only a single species each. The most diverse family in terms of the number of species was the Papilionaceae. The most abundant and important families in all sampled plots were: Loganiaceae, Annonceae, Apocynaceae, Sterculiaceae, Papilionaceae and Rhamnaceae (Appendix 2). These six families made up more than $50 \%$ of the total liana stems in the tropical seasonal rain forests of Xishuangbanna. 
TABLE 3

Distribution of stems ( $D$, stems $\left.h a^{-1}\right)$, number of species (SR), basal area $\left(B A, m^{2} h a^{-1}\right)$ and aboveground biomass $\left(A G B, \mathrm{~kg} \mathrm{ha}^{-1}\right)$ of lianas ( $\geq 2 \mathrm{~cm} \mathrm{dbh}$ ) according to their diameter classes (cm) in the three plots in the tropical seasonal rain forests in Xishuangbanna, SW China

\begin{tabular}{|c|c|c|c|c|c|c|c|c|c|c|c|c|c|c|c|c|}
\hline \multirow{2}{*}{$\begin{array}{l}\text { dbh } \\
\text { classes }\end{array}$} & \multicolumn{4}{|c|}{ Menglun plot } & \multicolumn{4}{|c|}{ Mengla plot } & \multicolumn{4}{|c|}{ Manyang plot } & \multicolumn{4}{|c|}{ Total for the three plots } \\
\hline & $\mathrm{D}$ & SR & BA & AGB & $\mathrm{D}$ & SR & BA & AGB & $\mathrm{D}$ & SR & BA & AGB & $\mathrm{D}$ & SR & $\mathrm{BA}$ & AGB \\
\hline $2-4$ & 102 & 35 & 0.074 & 867 & 61 & 32 & 0.044 & 515 & 38 & 20 & 0.034 & 385 & 201 & 69 & 0.152 & 1767 \\
\hline $4-6$ & 53 & 23 & 0.098 & 1041 & 43 & 21 & 0.077 & 803 & 45 & 22 & 0.078 & 836 & 141 & 53 & 0.254 & 2680 \\
\hline $6-8$ & 31 & 16 & 0.111 & 1093 & 22 & 7 & 0.082 & 807 & 15 & 12 & & 522 & 68 & 31 & 0.245 & 2422 \\
\hline $8-10$ & 16 & 12 & 0.093 & 874 & 4 & 3 & 0.027 & 254 & 9 & 9 & 0.056 & 524 & 29 & 22 & 0.177 & 1652 \\
\hline $10-15$ & 5 & 4 & 0.058 & 502 & 6 & 4 & 0.067 & 588 & 5 & 5 & 0.047 & 416 & 16 & 11 & 0.171 & 1506 \\
\hline$>15$ & 0 & 0 & 0 & 0 & 1 & 1 & 0.020 & 162 & 0 & 0 & 0 & 0 & 1 & 1 & 0.020 & 162 \\
\hline Total & 207 & 50 & 0.434 & 4377 & 137 & 38 & 0.318 & 3129 & 112 & 44 & 0.268 & 2682 & 456 & 95 & 1.020 & 10188 \\
\hline
\end{tabular}

Aboveground biomass: The dry aboveground biomass (AGB) is strongly linearly correlated with dbh $\left(\mathrm{R}^{2}=0.87\right.$; Fig. 1$)$. The linear regression equation can be described as:

$\ln (\mathrm{AGB})=0.1498+1.7895 * \ln (\mathrm{dbh})$

where AGB is the total aboveground biomass $(\mathrm{kg})$ of the individual lianas, and $\mathrm{dbh}(\mathrm{cm})$ is the diameter at breast height (Fig. 2)

The total aboveground biomass of lianas was $4377 \mathrm{~kg} / \mathrm{ha}$ for the Menglun plot, 3129 $\mathrm{kg} / \mathrm{ha}$ for the Mengla plot, and $2682 \mathrm{~kg} / \mathrm{ha}$ for the Manyang plot. The mean aboveground biomass of lianas was $3396 \mathrm{~kg} / \mathrm{ha}$, accounting for $1.4 \%$ of the total community aboveground biomass of $248000 \mathrm{~kg} / \mathrm{ha}$ (Feng et al. 1998).

Less than $2 \%$ of the total liana AGB has resulted from the lianas with $>15 \mathrm{~cm}$ dbh (Table 3). Lianas with $>10 \mathrm{~cm}$ in dbh (numbered 18 stems) accounted for $\sim 17 \%$ of the total liana AGB. About $43 \%$ of the liana AGB has resulted from lianas $\leq 4 \mathrm{~cm}$ dbh and $\sim 67 \%$ from lianas $\leq 6 \mathrm{~cm} \mathrm{dbh}$.

\section{DISCUSSION}

Liana abundance and diversity: Lower abundance and diversity of lianas were found in the present study as expected from the hypothesis of Schnitzer (2005). We counted only 152 liana stems ( $\geq 2 \mathrm{~cm} \mathrm{dbh})$ per hectare in the Xishuangbanna seasonal rain forests, which is much lower than other published data gained from the neotropical wet lowland forests. For example, 2471 liana stems ( $\geq 2 \mathrm{~cm}$ $\mathrm{dbh}$ ) per hectare were found in Bolivia (PérezSalicrup and Sork 2001), $450(\geq 2 \mathrm{~cm} \mathrm{dbh})$ in Costa Rica (Mascaro et al. 2004), and 606 $(\geq 2 \mathrm{~cm} \mathrm{dbh}$ ) in Panama (DeWalt and Chave 2004). For the tropical forests in Asia, Proctor (1983) recorded an average of 440 liana stems with $1-10 \mathrm{~cm}$ dbh per hectare in Sarawak, and Putz and Chai (1987) found an average of 348 stems in Sarawak valleys and 164 ( $>2 \mathrm{~cm} \mathrm{dbh})$ in hilltop sites. The abundance of lianas found in the present study is similar to the abundance at hilltop sites of Sarawak dipterocarp forest in Malaysia (Putz and Chai 1987), but much lower than that in other tropical wet and moist rain forests in Southeast Asia and in neotropcial forests.

Biodiversity indices varied with plots (Table 2). This site-dependent result may reflect the differences in abiotic and biotic conditions between plots. The species richness ranged from 38 to 50 species ( $\geq 2 \mathrm{~cm} \mathrm{dbh}$ ) per 1-ha plot. Similar to this finding, Pérez-Salicrup and Sork (2001) recorded 51 species/ha $(\geq 2 \mathrm{~cm})$ in a liana forest in Amazonian Bolivia. Putz (1984) found 65 liana species ( $\geq 2 \mathrm{~cm} \mathrm{dbh}$ ) per hectare on Barro Colorado Island, Panama. The liana species richness was $24 \sim 48$ species $(\geq 1 \mathrm{~cm})$ per hectare in the tropical dry forests 


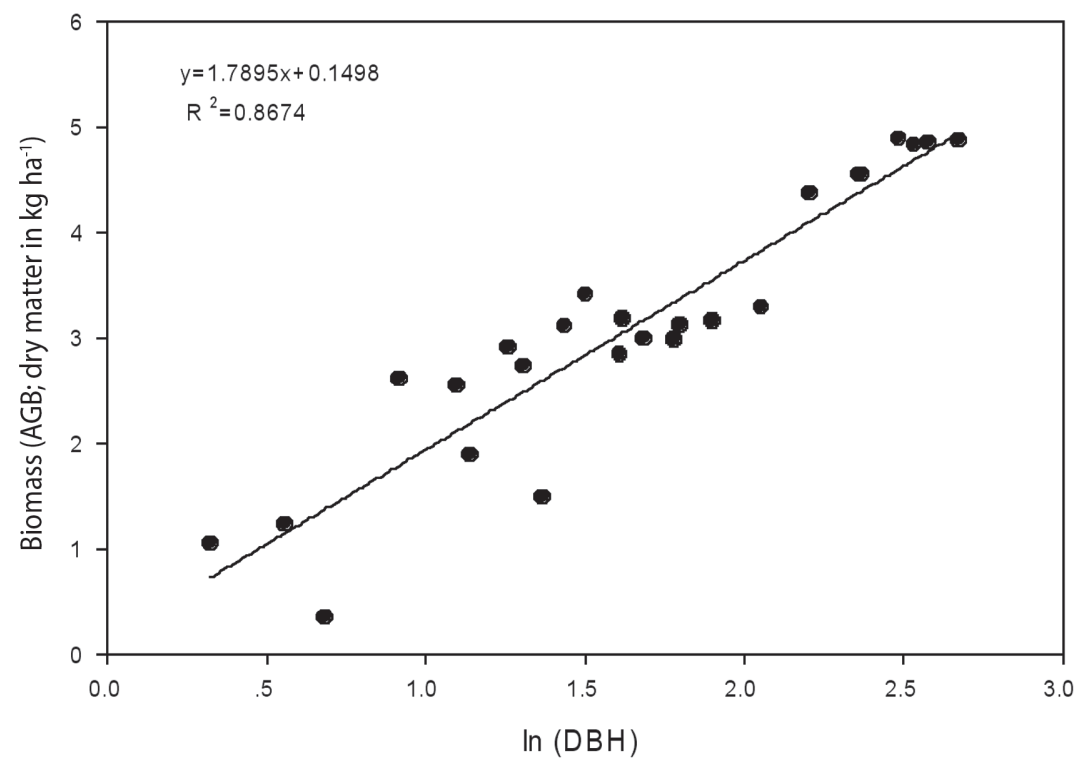

Fig. 2. Aboveground biomass (AGB; dry matter in $\mathrm{kg} \mathrm{ha}^{-1}$ ) in relation to the diameter (DBH in $\mathrm{cm}$ ) at $1.3 \mathrm{~m}$ stem height above the rooting point for lianas in the three plots in the tropical seasonal rain forests in Xishuangbanna, SW China.

of India (Muthuramkumar and Parthasarathy 2000, Reddy and Parthasarathy 2003). At a 0.1ha plot level, 7 12 species were found in this study compared to 8 species $(\geq 2.5 \mathrm{~cm})$ found in a 0.1-ha plot in the forest of Mexico (Lott et al. 1987). However, in Yasuní National Park in Ecuador, Nabe-Nielsen (2001) encountered 132 liana species in a 0.4 ha plot. Burnham (2002) recorded 311 liana species $(\geq 1 \mathrm{~cm} \mathrm{dbh})$ in a total of twelve 0.2 ha plots (i.e. in a total area of $2.4 \mathrm{ha}$ ). Due to the different plot size and dbh classification used, it is difficult to compare these different studies of liana richness exactly, but it seems that the species richness of lianas in the tropical seasonal rain forests in Xishuangbanna is similar to that found in tropical dry forests, but lower than that found in most tropical wet or moist forests.

The abundance and distribution of lianas usually depend on abiotic factors including elevation, rainfall and seasonality, soil fertility, and disturbance (Gentry 1991, Balfour and Bond 1993, Schnitzer and Bongers 2002). The liana abundance and diversity are thought to peak in the lowland tropics and decline with increasing latitude and elevations (Gentry 1991, Schnitzer and Bongers 2002). The relatively poor abundance and lower diversity of liana species found in the tropical seasonal rain forests in Xishuangbanna may be caused by the higher latitude, biotic and abiotic environments of this special tropical area. Xishuangbanna, located on the northern border of tropical Asia, is a transitional zone between the tropics and subtropics. The northward extension of the Asian tropical rain forest reaches its limits in Xishuangbanna in terms of both latitude and altitude (Cao et al. 1996). On the other hand, lianas abundance is strongly dependent on the availability of tree-fall gaps in dense tropical forests resulted from the natural and/or anthropogenic disturbance but negatively related with tree biomass (Putz 1983, Laurence et al. 2001, Schnitzer and Bongers 2002). In fact, it is well known that Xishuangbanna region is a calm tropical region with low wind speed (Liu et al. 2004). The plots studied are located in a well-protected natural reserve without any 
anthropogenic disturbance but high tree biomass. Lower wind speed and human disturbance, together with higher tree density and biomass, may result in lower liana density in the Xishuangbanna tropical forests. For the three plots, it is interesting to find that lianas density increased with decreasing tree density. It is possible that lianas species richness and density would increase with forest fragmentation in this area (Zhu et al. 2004).

Lianas composition: Variation of both species and family composition of lianas in the three plots are considerable. In the Menglun plot, S. cathayensis (28 individuals) and $S$. wallichiana (21 individuals) were the dominant lianas and each of them accounted for more than $10 \%$ of the total liana stems in the plot. $B$. grandifolia (34 individuals) and $S$. nitida (15 individuals) were dominant in the Mengla plot. Only one species, Bousigonia mekongensis (14 individuals) was dominant in the Manyang plot, accounted for more than $10 \%$ of the total liana stems. Several other studies have reported the dominance $(>10 \%)$ of a single species in local liana community (DeWalt et al. 2000, Nabe-Nielsen 2001, Burnham 2002). Different species dominated in different different plots may be the results of different micro-environmental conditions. Across the three plots, the top five dominant families were Loganiaceae, Annonceae, Papilionaceae, Apocynaceae and Rhamnaceae. This result shows a floristic affinity of tropical forest in this area to other Asian tropical area (Muthuramkumar and Parthasarathy 2000).

Biomass of lianas: To what extent of lianas biomass contributes to the community biomass in most tropical forests is currently unknown (Schnitzer and Bongers 2002). Our results showed an average lianas aboveground biomass of $3396 \mathrm{~kg} / \mathrm{ha}$ in the Xishuangbanna tropical seasonal rain forests, contributing to $1.4 \%$ of the total community aboveground biomass. In a Venezuelan forest, Putz (1983) estimated that lianas accounted for $4.5 \%$ (15 $700 \mathrm{~kg} / \mathrm{ha}$ ) of the total community AGB. In eastern Brazilian forests, this proportion was as high as $14 \%$ and the absolute sum reached $43000 \mathrm{~kg} / \mathrm{ha}$ (Gerwing and Farias 2000). In a study on lianas along a chronosequence in a central Panamanian lowland forest, DeWalt et al. (2000) found that the biomass of lianas was relatively constant with increased stand age, and ranged from 4050 to $11170 \mathrm{~kg} / \mathrm{ha}$. The lower liana biomass found in the present study may have resulted from the lower liana density and the lack of large lianas. For example, only 6 stems of lianas per hectare had a dbh of $>10$ $\mathrm{cm}$ in the tropical seasonal rain forests studied. Similarly, Rollet (1974) reported 5.6 large lianas (ranging from 1 to $17 \mathrm{stems} / \mathrm{ha}$ ) per hectare found in the southeastern Asian forests, but 9.4 large lianas (3-20 stems/ha) in Latin-America forests, and 9.4 large lianas (6-15 stems/ha) in African tropical forests. It seems that the Xishuangbanna tropical seasonal rain forests have less large lianas than the other two major moist forest blocks.

In summary, the abundance, diversity and biomass of lianas in Xishuangbanna seasonal tropical rain forests are lower than those in tropical moist and wet forests, but similar to those in tropical dry forests in India and Mexico. Such results could be caused by following factors: 1) Xishuangbanna is biogeographically located in a transitional zone from tropical Southeast Asia to subtropical East Asia, and the Xishuangbanna tropical forests are, therefore, one of the northernmost tropical rain forests in the world; 2) Xishuangbanna is a calm tropical region with lower wind speeds. The forests have then been protected from catastrophic disturbance by hurricanes; 3) all the plots are located in a Natural Reserve, which protects them from human disturbance. Factors 2 and 3 are likely to affect liana occurrence as natural and anthropogenic disturbances which are usually thought to promote liana abundance (Schnitzer and Bongers 2002, Rice et al. 2004). Comparing the lianas occurrence across the tropical forests around the world, the present study suggests that the distribution of lianas in tropical forests is determined by the geographical location associated with the climatic 
conditions on a global scale. However, the local disturbance and microhabitat will modify the abundance and biomass of lianas on a regional and local scale. The present study emphasizes that other factors beyond the amount and seasonality of precipitation should be included when considering the liana abundance patterns across scales.

\section{ACKNOWLEDGMENTS}

We are very grateful to Lu Yun, Chen Defu and many others for their valuable assistance in the field survey. We also express our gratitude to Tao Guoda for his help in the identification of some specimens, and to S. Dingwall for linguistic improvement of the English. Comments and suggestions from two anonymous reviewers significantly improved this manuscript. This study was jointly supported by the CAS Project of Knowledge Innovation (No. KZCX1-SW-01), "West Light Foundation of the Chinese Academy of Sciences" and the Field Station Foundation of CAS.

\section{RESUMEN}

Las lianas son componentes importantes de los bosques tropicales y tienen importantes impactos en la diversidad, la estructura y la dinámica de los bosques tropicales. El presente estudio documenta la flora de lianas en una región tropical estacional china. La riqueza de especies, abundancia, clases de tamaño y patrones espaciales de distribución de las lianas fueron investigados en tres parcelas de una hectárea de bosque tropical estacional lluvioso, en Xishuangbanna, SW China. Todas las lianas con $\geq 2 \mathrm{~cm}$ de diámetro a la altura del pecho (DAP) fueron medidas, etiquetadas e identificadas. Un total de 458 tallos de lianas pertenecientes a 95 especies (que van de 38 a 50 especies/ha), 59 géneros y 32 familias se registraron en las tres parcelas. Las familias mejor representadas fueron Loganiaceae, Annonceae, Papilionaceae, Apocynaceae y Rhamnaceae. Papilionaceae (14 especies registradas) fue la de mayor importancia. La densidad de población, área basal y el índice de valor de importancia (IVI) varió mucho a través de las tres parcelas. Strychnos cathayensis, Byttneria grandifolia y Bousigonia mekongensis fueron las especies dominantes en términos de IVI en las tres parcelas. La media de la biomasa aérea de lianas (3 396 $\mathrm{kg} / \mathrm{ha}$ ) representó el $1.4 \%$ de la biomasa aérea total de la comunidad. La abundancia, biomasa y diversidad de lianas en bosques tropicales estacionales de Xishuangbanna son inferiores a los de zonas tropicales y bosques húmedos, pero superiores a los de los bosques tropicales secos. Este estudio proporciona nuevos datos sobre las lianas de una región geográfica que ha sido poco estudiada. Los resultados enfatizan que otros factores, además de la cantidad y la estacionalidad de la precipitación, deben ser considerados al examinar los patrones de la abundancia de lianas.

Palabras clave: biodiversidad, liana, abundancia, biomasa, riqueza de especies, bosque tropical.

\section{REFERENCES}

Balfour, D. \& W. Bond. 1993. Factors limiting climber distribution and abundance in a southern African forest. J. Ecol. 6: 93-99.

Burnham, R.J. 2002. Dominance, diversity and distribution of lianas in Yasuní, Ecuador: who is on top? J. Trop. Ecol. 18: 845-864.

Burnham, R.J. 2004. Alpha and beta diversity of lianas in Yasuní, Ecuador. For. Ecol. Manage. 190: 43-55.

Cao, M. \& J.H. Zhang. 1997. Tree species diversity of tropical forest vegetation in Xishuangbanna, SW China. Biodivers. Conserv. 6: 995-1006.

Cao, M., J.H. Zhang, Z.L. Feng, J.W. Deng \& X.B. Deng. 1996. Tree species composition of a seasonal rain forest in Xishuangbanna, Southwest China. Trop. Ecol. 37: 183-192.

Curtis, J.T. \& G.. Cottam. 1962. Plant Ecology Workbook. Burgess Publishing Co., Minneapolis, USA.

DeWalt, S.J. \& J. Chave. 2004. Structure and biomass of four lowland neotropical forests. Biotropica 36: 7-19.

DeWalt, S.J., S.A. Schnitzer \& J.S. Denslow. 2000. Density and diversity of lianas along a chronosequence in a central Panamanian lowland forest. J. Trop. Ecol. 16: 1-19.

Feng, Z.L., Z. Zheng, J.H. Zhang, M. Cao, L.Q. Sha \& J.W. Deng. 1998. Biomass and its allocation of a tropical wet seasonal rain forest in Xishuangbanna. Acta Phytoecol. Sinica 22: 481-488.

Fisher, R.A., A.S. Corbet \& C.B. Williams. 1943. The relation between the number of species and the number of individuals in a random sample of an animal population. J. Anim. Ecol. 12: 42-58.

Gentry, A.H. 1991. The distribution and evolution of climbing plants, p. 3-52. In F.E. Putz \& H.A. Mooney (eds.). The biology of vines. Cambridge University , Cambridge England. 
Gentry, A.H. \& C. Dodson. 1987. Contribution of nontrees to species richness of a tropical rain forest. Biotropica 19: 149-156.

Gerwing, J.J. \& D.L. Farias. 2000. Integrating liana abundance and forest stature into an estimate of total aboveground biomass for an eastern Amazonian forest. J. Trop. Ecol. 16: 327-335.

Gerwing, J.J., S.A. Schnitzer, R.J. Burnham, F. Bongers, J. Chave, S.J. DeWalt, C.E.N. Ewango, R. Foster, D. Kenfack, M. Martínez-Ramos, M. Parren, N. Parthasarathy, D.R. Pérez-Salicrup, F.E. Putz \& D.W. Thomas. 2006. A standard protocol for liana censuses. Biotropica 38: 256-261.

Hill, M.O. 1973. Diversity and evenness: A unifying notation and its consequences. Ecology 54: 427-432.

Laurance, W.F., D. Pérez-Salicrup, P. Delamônica, P.M. Fearnside, S. D'angelo, A. Jerozolinski, L. Pohl \& T.E. Lovejoy. 2001. Rain forest fragmentation and the structure of Amazonian liana communities. Ecology 82: $105-116$.

Li, Y.H., S.J. Pei \& Z.F. Xu. 1996. List of plants in Xishuangbanna. Yunnan National, Kunming, China.

Liu, W.J., F.R. Meng, Y.P. Zhang, Y.H. Liu \& H.M. Li. 2004. Water input from fog drip in the tropical seasonal rainforest of Xishuangbanna, SW China. J. Trop. Ecol. 20: 517-524.

Lott, E.J., S.H. Bullock \& J.A. Magallanes. 1987. Floristic diversity and structure of upland and Arroyo forests of Coastal Jalisco. Biotropica 19: 228-235.

Magurran, A. 1988. Ecological diversity and its measurement. Princeton University, New Jersey, USA.

Mascaros, J., S.A. Schnitzer \& W.P. Carsonc. 2004. Liana diversity, abundance, and mortality in a tropical wet forest in Costa Rica. For. Ecol. Manage. 190: 3-14.

Mori, S.A., B.M. Boom, A.M. De Carvalho \& T.S. Dos Santos. 1983. Southern Bahian moist forests. Bot. Rev. 49: 155-232.

Muthuramkumar, S. \& N. Parthasarathy. 2000. Alpha diversity of lianas in a tropical evergreen forest in the Anamalais, Western Ghats, India. Divers. Distrib. 6: 1-14.

Nabe-Nielsen, J. 2001. Diversity and distribution of lianas in a neotropical rain forest, Yasun National Park, Ecuador. J. Trop. Ecol. 17: 1-19.
Pérez-Salicrup, D.R. \& V.L. Sork. 2001. Lianas and trees in a liana forest of Amazonian Bolivia. Biotropica 33: 34-47.

Proctor, J. 1983. Ecological studies in four contrasting lowland rain forest in Gunung Mulu National Park, Sarawak. I. Forest environment, structure and floristics. J. Ecol. 71: 237-260.

Putz, F.E. 1983. Liana biomass and leaf area of a "tierra firme" forest in the Rio Negro basin, Venezuela. Biotropica 15: 185-189.

Putz, F.E. 1984. The natural history of lianas on Barro Colorado Island, Panama. Ecology 65: 1713-1724.

Putz, F.E. \& P. Chai. 1987. Ecological studies on lianas in Lambir National Park, Sarawak, Malaysia. J. Ecol. 75: 523-531.

Reddy, M.S. \& N. Parthasarathy. 2003. Liana diversity and distribution in four tropical dry evergreen forests on the Coromandel coast of south India. Biodivers. Conserv. 12: 1609-1627.

Rice, K., N. Brokaw \& J. Thompson. 2004. Liana abundance in a Puerto Rican forest. For. Ecol. Manage. $190: 33-41$.

Rollet, B. 1974. L'architecture des forêts denses humides semper-virentes de plaine. Nogentsur-Marne: Centre Technique Forestier Tropical, France.

Schnitzer, S.A. 2005. A mechanistic explanation for global patterns of liana abundance and distribution. Am. Nat. 166: 262-276.

Schnitzer, S.A. \& F. Bongers. 2002. The ecology of lianas and their role in forests. Trends Ecol. Evol. 17: 223-230.

Schnitzer, S.A., J.W. Dalling \& W.P. Carson. 2000. The impact of lianas on tree regeneration in tropical forest canopy gaps: evidence for an alternative pathway of gap-phase regeneration. J. Ecol. 88: 655-666.

Shanmughavel, P., Z. Zheng, L.Q. Sha \& M. Cao. 2001. Floristic structure and biomass distribution of a tropical seasonal rain forest in Xishuangbanna, southwest China. Biom. Bioen. 21: 165-175.

Zhu, H., Z.F. Xu, H. Wang \& B.G. Li. 2004. Tropical rain forest fragmentation and its ecological and species diversity changes in southern Yunnan. Biodivers. Conserv. 13: 1355-1372. 


\section{APPENDIX 1}

Density (stems per hectare), frequency and basal area $\left(\mathrm{m}^{2} \mathrm{ha}^{-1}\right)$ of the ten species with the highest importance value index (IVI) in the tropical seasonal rain forests in Xishuangbanna, SW China.

\begin{tabular}{|c|c|c|c|c|}
\hline Species & Density & Frequency & Basal area & IVI \\
\hline \multicolumn{5}{|l|}{ Menglun Plot } \\
\hline Strychnos cathayensis & 28 & 20 & 343.47 & 33.94 \\
\hline Strychnos wallichiana & 21 & 16 & 331.89 & 27.79 \\
\hline Uvaria maclurei & 11 & 6 & 656.11 & 24.19 \\
\hline Combretum latifolium & 10 & 8 & 309.80 & 16.97 \\
\hline Zizyphus attopensis & 10 & 7 & 307.40 & 16.29 \\
\hline Tetracera asiatica & 16 & 6 & 186.60 & 15.78 \\
\hline Salacia polysperma & 11 & 9 & 88.45 & 12.98 \\
\hline Aganosma navaillei & 9 & 7 & 184.09 & 12.97 \\
\hline Premna fulva & 9 & 6 & 185.60 & 12.37 \\
\hline Acacia rugata & 7 & 5 & 168.73 & 10.40 \\
\hline \multicolumn{5}{|l|}{ Mengla Plot } \\
\hline Byttneria grandifolia & 34 & 22 & 948.56 & 74.17 \\
\hline Strychnos nitida & 15 & 13 & 661.95 & 43.31 \\
\hline Fissistigma oldhamii & 10 & 9 & 162.14 & 20.37 \\
\hline Tetrastigma planicaulum & 8 & 5 & 167.71 & 15.55 \\
\hline Tetrastigma crucistum & 5 & 5 & 144.71 & 12.63 \\
\hline Tetrastigma rubpstre & 2 & 2 & 208.79 & 9.81 \\
\hline Derris marginata & 5 & 5 & 52.81 & 9.74 \\
\hline Ventilago inaequilateralis & 4 & 4 & 100.16 & 9.61 \\
\hline Capparis fohaiensis & 5 & 3 & 49.83 & 7.87 \\
\hline Iodes cirrhosa & 4 & 4 & 38.96 & 7.69 \\
\hline \multicolumn{5}{|l|}{ Manyang Plot } \\
\hline Bousigonia mekongensis & 14 & 6 & 290.57 & 29.82 \\
\hline Gnetum montanum & 10 & 10 & 118.50 & 24.11 \\
\hline Strychnos nitida & 5 & 4 & 272.45 & 18.95 \\
\hline Fissistigma minuticalyx & 7 & 6 & 142.45 & 18.03 \\
\hline Derris marginata & 7 & 7 & 95.59 & 17.35 \\
\hline Gnetum montanum & 5 & 4 & 184.34 & 15.66 \\
\hline Ventilago calyculata & 3 & 3 & 112.13 & 10.10 \\
\hline Milletia dielsiana & 2 & 2 & 163.18 & 10.04 \\
\hline Strychnos wallichiana & 4 & 4 & 53.91 & 9.89 \\
\hline Paederia scandens & 4 & 3 & 62.87 & 9.15 \\
\hline
\end{tabular}




\section{APPENDIX 2}

The top ten important families with the highest family importance value (FIV) in the tropical seasonal rain forests in Xishuangbanna, SW China.

\begin{tabular}{|c|c|c|c|c|}
\hline Family & No. of species & Density (stems ha-1) & Basal area $\left(\mathrm{m}^{2} \mathrm{ha}^{-1}\right)$ & FIV \\
\hline \multicolumn{5}{|l|}{ Menglun Plot } \\
\hline Loganiaceae & 3 & 52 & 730.70 & 47.98 \\
\hline Annonceae & 6 & 20 & 929.48 & 43.10 \\
\hline Apocynaceae & 4 & 13 & 380.02 & 23.05 \\
\hline Papilionaceae & 6 & 11 & 244.40 & 22.95 \\
\hline Rhamnaceae & 3 & 14 & 350.76 & 20.85 \\
\hline Mimosaceae & 3 & 13 & 302.09 & 19.25 \\
\hline Dilleniaceae & 1 & 16 & 186.60 & 14.03 \\
\hline Combretaceae & 1 & 10 & 309.80 & 13.98 \\
\hline Rubiaceae & 3 & 8 & 131.17 & 12.89 \\
\hline Hippocrateaceae & 2 & 12 & 92.36 & 11.93 \\
\hline \multicolumn{5}{|l|}{ Mengla Plot } \\
\hline Sterculiaceae & 1 & 34 & 948.56 & 57.33 \\
\hline Vitaceae & 4 & 17 & 550.05 & 40.26 \\
\hline Loganiaceae & 1 & 15 & 661.95 & 34.43 \\
\hline Papilionaceae & 7 & 14 & 148.38 & 33.31 \\
\hline Annonceae & 3 & 14 & 200.20 & 24.42 \\
\hline Apocynaceae & 3 & 8 & 84.73 & 16.40 \\
\hline Celastraceae & 3 & 3 & 89.42 & 12.90 \\
\hline Convolvulaceae & 3 & 4 & 34.95 & 11.92 \\
\hline Hippocrateaceae & 2 & 4 & 50.80 & 9.78 \\
\hline Rhamnaceae & 1 & 4 & 100.16 & 8.71 \\
\hline \multicolumn{5}{|l|}{ Manyang Plot } \\
\hline Apocynaceae & 3 & 18 & 367.35 & 36.63 \\
\hline Gnetaceae & 3 & 17 & 326.52 & 34.21 \\
\hline Rhamnaceae & 5 & 11 & 301.91 & 32.47 \\
\hline Papilionaceae & 3 & 10 & 277.47 & 26.12 \\
\hline Annonceae & 4 & 10 & 210.52 & 25.89 \\
\hline Loganiaceae & 2 & 9 & 326.36 & 24.78 \\
\hline Celastraceae & 3 & 4 & 129.00 & 15.21 \\
\hline Rubiaceae & 2 & 5 & 129.79 & 13.86 \\
\hline Convolvulaceae & 2 & 4 & 152.33 & 13.81 \\
\hline Hippocrateaceae & 3 & 3 & 77.11 & 12.38 \\
\hline \multicolumn{5}{|l|}{ Three plots in all } \\
\hline Loganiaceae & 3 & 76 & 1719.01 & 36.699 \\
\hline Annonceae & 9 & 44 & 1340.19 & 32.278 \\
\hline Papilionaceae & 14 & 35 & 674.15 & 29.030 \\
\hline Apocynaceae & 6 & 39 & 832.10 & 23.036 \\
\hline Rhamnaceae & 7 & 29 & 752.83 & 21.118 \\
\hline Sterculiaceae & 1 & 38 & 1011.42 & 19.314 \\
\hline Vitaceae & 4 & 19 & 601.80 & 14.285 \\
\hline Gnetaceae & 3 & 20 & 359.43 & 11.072 \\
\hline Rubiaceae & 5 & 13 & 260.96 & 10.676 \\
\hline Hippocrateaceae & 4 & 19 & 220.26 & 10.539 \\
\hline
\end{tabular}

